\title{
Glycine betaine transport by Staphylococcus aureus: evidence for feedback regulation of the activity of the two transport systems
}

\author{
Bizhan Pourkomailian and Ian R. Booth \\ Author for correspondence: Ian R. Booth. Tel: +44224 273152. Fax: +44224273144.
}

Department of Molecular and Cell Biology, Marischal College, Aberdeen AB9 1AS, UK

\begin{abstract}
The regulation of glycine betaine accumulation by Staphylococcus aureus was investigated. The accumulation of glycine betaine was regulated by the osmotic pressure of the medium and the low affinity transport system played the major role in this regulation. Mutants were isolated that lack the low affinity, osmotically activated glycine betaine/proline transport system. Such mutants accumulated glycine betaine via the high affinity system but the glycine betaine pool was smaller and responded poorly to osmotic pressure changes. The regulation of glycine betaine transport has revealed that at the steady state net influx is reduced and that this is achieved by inhibition of both the low affinity and the high affinity transport systems. Cells pre-loaded with glycine betaine exhibited a reduced $V_{\max }$ for both systems: the low affinity system was reduced in activity fivefold and the high affinity system was reduced 10-fold and became virtually undetectable. Although glycine betaine transport at the steady state is reduced, retention of the compatible solute is an active process since addition of an uncoupler provokes rapid release of the accumulated material. These data suggest that feedback regulation of the activity of the uptake systems is a major mechanism for controlling the level of compatible solute accumulation.
\end{abstract}

Keywords: Glycine betaine, transport, osmoregulation, Staphylococcus aureus

\section{INTRODUCTION}

One of the characteristic features of Stapbylococcus aureus is its tolerance of low water activities. This organism, which can grow in media containing up to $3 \mathrm{M} \mathrm{NaCl}$, is among the most osmo-tolerant bacterial species and is a major cause of food poisoning. Recent studies on $S$. aureus have begun to clarify our understanding of osmotic adaptation in this organism. Proline and glycine betaine are the two major osmoprotectants, although choline can also be utilized for this purpose after conversion to glycine betaine in the cytoplasm. Unlike the glycine betaine and proline transport systems, which are constitutive, that for choline is inducible by osmotic stress (Kaenjak et al., 1993). In cells grown and incubated at low osmolarity the proline and betaine transport systems display a low activity. The activation of proline transport system(s) in response to osmotic stress is well established (Koujima et al., 1978; Anderson \& Witter, 1982). Subsequently, it was

Abbreviations: AC, azetidine carboxylate; CCCP, carbonyl cyanide $m$ chlorophenylhydrazone. shown that there are two proline transport systems in $S$. aureus: a high affinity system, insensitive to osmotic stress, and a low affinity transport system, activated by osmotic stress (Bae \& Miller, 1992; Townsend \& Wilkinson, 1992).

The accumulation of the compatible solute glycine betaine is also activated by osmotic stress (Miller et al., 1991; Graham \& Wilkinson, 1992; Pourkomailian \& Booth, 1992). In defined medium, glycine betaine was shown to be more effective than proline in enhancing the growth of cells in the presence of $15 \% \mathrm{NaCl}$ (Miller et al., 1991; Graham \& Wilkinson, 1992). Analysis of the transport systems that mediate glycine betaine accumulation has yielded different results in two laboratories. We demonstrated the presence of two glycine betaine transport systems that differ in their $K_{\mathrm{m}}$ values for glycine betaine, in their degree of inhibition by proline and its toxic analogues and in their activation by osmotic pressure (Pourkomailian \& Booth, 1992). The low affinity glycine betaine transport system was shown to be inhibited by proline and was activated by osmotic pressure in a manner that was similar to that previously reported for the low 
affinity proline transport system. We inferred from these data that the low affinity glycine betaine transport system might be identical to the osmotically activated proline transport system already described by others (Bae \& Miller, 1992; Townsend \& Wilkinson, 1992). In contrast, the same strain of $S$. aureus was subsequently reported to contain a single, moderate affinity $\left(K_{\mathrm{m}} 90 \mu \mathrm{M}\right)$ transport system that was activated by osmotic pressure (Bae et al., 1993).

The current studies were undertaken to investigate the mechanism of regulation of the glycine betaine pool and to determine whether regulation of the transport activities is the basis of the discrepancy between the various studies on glycine betaine transport in $S$, aureus.

\section{METHODS}

Bacterial strain and culture conditions. Staphylococcus aureus RN4220 (from Dr G. S. A. B. Stewart, University of Nottingham, UK) was grown in the defined medium of Pattee \& Neveln (1975). This medium contains a defined mixture of amino acids, vitamins, purines and pyrimidines and glucose as the major carbon source. Cultures were grown in $250 \mathrm{ml}$ Erlenmeyer flasks at $37^{\circ} \mathrm{C}$ overnight using a low culture volume $(50 \mathrm{ml})$ to ensure good aeration. Mutant strain BP100 is a spontaneous streptomycin resistant mutant isolated by plating $0.1 \mathrm{ml}$ of an overnight culture of RN4220 on minimal medium plates containing $100 \mu \mathrm{g}$ streptomycin $\mathrm{ml}^{-1}$. Strain RN4220 carrying plasmid pTV1 ts and bacteriophage $\phi 85$ were the generous gift of Professor T. J. Foster (Trinity College, Dublin, Ireland).

Transport assays. Cultures were grown overnight in defined medium; diluted 25 -fold, and grown at $37^{\circ} \mathrm{C}$ until the $\mathrm{OD}_{600}$ reached 0.7 (LKB Spectronic). Cells were harvested by centrifugation and washed twice by re-suspension and centrifugation in $0.045 \mathrm{M}$ potassium phosphate buffer, $\mathrm{pH} \mathrm{7}$, and stored on ice until required. Transport assays were conducted at $30^{\circ} \mathrm{C}$ in $0.045 \mathrm{M}$ phosphate buffer (potassium salt), $\mathrm{pH} 7$, containing $10 \mathrm{mM} \mathrm{NaCl}$. Aliquots of cells $(2 \mathrm{ml})$ were incubated at approximately $60 \mu \mathrm{g}$ protein $\mathrm{ml}^{-1}\left(\mathrm{OD}_{600}=0.5\right)$ for $5 \mathrm{~min}$ prior to the addition of $\left[N-\right.$ metbyl $\left.l^{14} \mathrm{C}\right]$ glycine betaine $\left(55 \mu \mathrm{Ci} \mu \mathrm{mol}^{-1}\right.$;

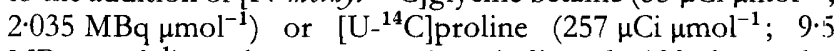
$\mathrm{MBq} \mu \mathrm{mol}^{-1}$ ) at the concentrations indicated; $100 \mu \mathrm{l}$ samples were removed, filtered through GFF (Whatman) filter discs under vacuum and the filtered cells washed with $3 \mathrm{ml}$ phosphate buffer. After drying, the filters were inserted into disposable plastic scintillation vials with $2 \mathrm{ml}$ Ultima Gold scintillant (Packard) and counted for at least $10 \mathrm{~min}$ on a pre-set programme on a Packard 300C scintillation counter. Controls were analysed using boiled cells to establish the background binding of glycine betaine to cells and filters and appropriate corrections were applied. Exchange reactions at the steady state were assayed by allowing cells to accumulate unlabelled glycine betaine $(500 \mu \mathrm{M})$, as in a normal transport experiment, for 30-40 min. A small volume of radioactive glycine betaine (specific activity $55 \mathrm{mCi} \mathrm{mmol}^{-1}$; stock concentration $3.8 \mathrm{mM}$ ) was then added and the rate of radioactive solute accumulation determined as described above.

To pre-load cells with glycine betaine, the cells were harvested as above and incubated in assay buffer at $30^{\circ} \mathrm{C}$ with $500 \mu \mathrm{M}$ glycine betaine for $45 \mathrm{~min}$. The cell suspension was then filtered and washed with $3 \mathrm{ml}$ assay buffer to remove the external betaine and the cells re-suspended in $2 \mathrm{ml}$ pre-warmed assay buffer and the uptake experiment carried out as described. The rate of loss of glycine betaine from such cells was determined by loading cells with $500 \mu \mathrm{M}$ radiolabelled glycine betaine $(2 \mu \mathrm{Ci}$ $\left.\mu \mathrm{mol}^{-1}\right)$, filtering, washing the cells as above and resuspension in medium at the same osmolarity and incubation at $30^{\circ} \mathrm{C}$. Retention of radioactivity was measured as described for transport assays. All experiments have been carried out in triplicate and data points represent the mean of two separate sets of data points generated with the same batch of cells.

The relationship between optical density and protein concentration was established by serial dilution of exponential phase cultures and lysis of the cells of known $\mathrm{OD}_{600}$ with $0.1 \mathrm{M}$ $\mathrm{NaOH}$. The protein content was measured by the FolinCiocalteau method adapted for microtitre plates using a bovine serum albumin standard. A cell suspension giving an $\mathrm{OD}_{600}=1$ was equivalent to approximately $120 \mu \mathrm{g}$ total protein $\mathrm{ml}^{-1}$.

Analogue toxicity. Analogue toxicity was determined by the filter disc method. Aliquots $(10 \mu \mathrm{l})$ of a toxic proline analogue were pipetted onto sterile filter discs (5 mm diameter) placed in the centre of an agar plate spread with $0.1 \mathrm{ml}$ of an overnight culture. After incubation for $48 \mathrm{~h}$ the zone of inhibition was measured across two diameters at $90^{\circ}$ to each other. Two concentrations of azetidine carboxylate (AC) were used: $3 \mathrm{M}$ and $5 \mathrm{M}$. S. aureus has a requirement for proline for growth and we have previously shown that proline and $\mathrm{AC}$ are transported by the same system. Thus, the basic growth medium was modified by the exclusion of free proline and the incorporation of the peptide Pro-Gly $(1 \mathrm{mM})$ to supply proline via the peptide uptake system.

Mutant isolation. Mutants of $S$. aureus resistant to AC were isolated in two different ways. Spontaneous mutants (strains BP101-105) were isolated as colonies growing within the zone of inhibition created by AC $(3 \mathrm{M})$ placed on a sterile filter disc in the centre of a plate spread with $0.1 \mathrm{ml}$ of an overnight culture (as above). Strain BP106 is a derivative of strain BP105 and was isolated from the zone of inhibition created by a filter disc carrying $5 \mathrm{M}$ AC. Transposon Tn 917 mutants were created using plasmid pTV1ts. A transposon pool was created by overnight incubation of RN4220/pTV1ts at $42^{\circ} \mathrm{C}$ in defined medium [at this temperature the plasmid cannot replicate and erythromycin resistant survivors arise by transposition of Tn917(Erm) into the chromosome]. Aliquots $(100 \mu \mathrm{l})$ of the overnight survivors were plated onto defined medium plates containing: Pro-Gly peptide $(1 \mathrm{mM}), 0.7 \mathrm{M} \mathrm{NaCl}$ to activate the glycine betaine/proline transport system, and erythromycin $\left(10 \mu \mathrm{g} \mathrm{ml}^{-1}\right)$. A filter disc carrying $10 \mu \mathrm{l} 5 \mathrm{M} \mathrm{AC}$ was placed in the centre of the plate and the plates incubated at $37^{\circ} \mathrm{C}$. Resistant colonies were picked from the inhibition zone, purified and the resistance of each strain to AC was determined as described above. The most resistant strain, BP107, was taken for transduction into a clean genetic background to verify that the mutant phenotype was linked with the transposon insertion. The Tn917 insertion was transduced into strain BP100 using bacteriophage $\phi 85$. An aliquot $(100 \mu \mathrm{l})$ of an overnight culture of strain BP107 was inoculated into complex medium LK (Rowland et al., 1984) containing $1 \mathrm{mM} \mathrm{CaCl}_{2}$ and incubated in a shaking incubator at $37^{\circ} \mathrm{C}$ for $4 \mathrm{~h}$. A dilution $\left(10^{-3}\right)$ of the $\phi 85$ stock was prepared using LK as diluent and $200 \mu \mathrm{l}$ was added to $300 \mu \mathrm{l}$ of cells. Molten LK agar $(10 \mathrm{ml}, 0.5 \%$, w/v) containing $1 \mathrm{mM} \mathrm{CaCl}_{2}$ was added to the cells/phage mixture and immediately poured onto $\mathrm{LK}$ agar plates containing $1 \mathrm{mM} \mathrm{CaCl}_{2}$ and the plates incubated at $37^{\circ} \mathrm{C}$ overnight in a plastic bag to retain moisture. The top layer of the lysed cells and phage was scraped off the plate into a sterile Oakridge centrifuge tube and was spun in a bench centrifuge at 10000 r.p.m. for $10 \mathrm{~min}$. The supernatant was removed, was filtered through a $0.45 \mu \mathrm{m}$ filter and was stored at $4{ }^{\circ} \mathrm{C}$ for use in transduction. An aliquot 
$(500 \mu \mathrm{l})$ of a mid-exponential phase culture of BP100 was harvested and suspended in $1 \mathrm{ml} \mathrm{LK}$ containing $1 \mathrm{mM} \mathrm{CaCl}_{2}$ and $500 \mu \mathrm{l}$ of the fresh phage preparation added. The mixture was incubated for $10 \mathrm{~min}$ at room temperature and then $1 \mathrm{ml}$ ice-cold $0.02 \mathrm{M}$ sodium citrate was added and the cells harvested and re-suspended in $1 \mathrm{ml} 0.02 \mathrm{M}$ sodium citrate and incubated on ice for $2 \mathrm{~h}$. Aliquots $(100 \mu \mathrm{l})$ were plated onto LK plates containing: streptomycin $\left(100 \mu \mathrm{g} \mathrm{ml}^{-1}\right)$, erythromycin $(10 \mu \mathrm{g}$ $\left.\mathrm{ml}^{-1}\right)$ and sodium citrate $(2 \mathrm{mM})$. The plates were incubated at $37^{\circ} \mathrm{C}$ for $72 \mathrm{~h}$ to recover transductants. The transductants were purified on LK medium containing streptomycin $\left(100 \mu \mathrm{g} \mathrm{ml}^{-1}\right)$ and erythromycin $\left(10 \mu \mathrm{g} \mathrm{ml}^{-1}\right)$ and were then tested for resistance to $\mathrm{AC}$ by measuring the zone of inhibition caused by $10 \mu \mathrm{l} 5 \mathrm{M} \mathrm{AC}$.

Chemicals. Biochemicals were purchased from Sigma and Boehringer; inorganic components and buffers were Analar grade and were purchased from $\mathrm{BDH}$. Complex media, for the maintenance of cell cultures, were purchased from Oxoid. Radioactive materials were purchased from Amersham and ICN.

\section{Table 1. Inhibition of growth of S. aureus by AC}

Sensitivity to AC was determined as described in Methods. The peptide was Pro-Gly and was present at a final concentration of $1 \mathrm{mM}$.

\begin{tabular}{|c|c|c|}
\hline \multirow[t]{2}{*}{ Strain } & \multicolumn{2}{|c|}{$\begin{array}{c}\text { Zone size with } 5 \mathrm{M} \mathrm{AC} \\
(\mathrm{mm})\end{array}$} \\
\hline & +Proline & + Peptide \\
\hline RN4220 & $2 \cdot 0 \pm 1 \cdot 0$ & $53 \cdot 0 \pm 1 \cdot 5$ \\
\hline BP101 & $1 \cdot 0 \pm 1 \cdot 0$ & $5.5 \pm 0.5$ \\
\hline BP102 & $1.5 \pm 0.5$ & $8 \cdot 0 \pm 1 \cdot 0$ \\
\hline BP103 & $1 \cdot 5 \pm 1 \cdot 0$ & $8 \cdot 0 \pm 1 \cdot 5$ \\
\hline BP104 & $1 \cdot 5 \pm 1 \cdot 0$ & $8 \cdot 0 \pm 1 \cdot 0$ \\
\hline BP106 & $0 \cdot 0$ & $0 \cdot \overline{0}$ \\
\hline BP107 & $0 \cdot 0$ & $0 \cdot 0$ \\
\hline BP108 & $0 \cdot 0$ & $0 \cdot 0$ \\
\hline
\end{tabular}

\section{RESULTS}

\section{Mutants deficient in the low affinity transport system}

We have previously shown that the low affinity glycine betaine/proline uptake system also transports the toxic proline analogue, azetidine carboxylic acid (AC). In contrast, the high affinity system was unaffected by $\mathrm{AC}$ (Pourkomailian \& Booth, 1992). We isolated AC-resistant mutants to determine whether the low affinity transport of betaine and proline was carried out by the same protein. $S$. aureus requires proline for growth and this interferes with isolation of mutants resistant to $\mathrm{AC}$ due to the competition between the substrate and the analogue for a single transport system. However, if the proline requirement was supplied via a peptide, such as Pro-Gly, AC sensitivity was readily demonstrated (Table 1 ). Mutants resistant to AC were isolated as spontaneous isolates (BP101-104) from the zone of inhibition around a disc containing $3 \mathrm{M}$ AC. Strains BP106 and BP107 (a Tn917 insertion mutant) were isolated from plates carrying discs containing $5 \mathrm{M}$ AC. When the transposon insertion in strain BP107 was transduced into a clean genetic background all of the transductants were found to be AC resistant, thus confirming the genetic linkage between the transposon and the resistance to AC. In general, the spontaneous mutants were more sensitive to $A C$ than was the transposon mutant, suggesting impaired transport function in these strains rather than complete elimination of the transport system.

Kinetic analysis of a number of AC-resistant mutants revealed that glycine betaine transport via the low affinity uptake system was severely impaired (Table 2) compared with the wild-type strain RN4220. The $V_{\max }$ of the low affinity system was reduced in all the mutants (Table 2). Strain BP101, a spontaneous AC-resistant mutant, appears to be affected in both the $K_{\mathrm{m}}$ and $V_{\max }$ of the low affinity system, an observation typical of missense mutations that affect carrier activity (Table 2). Mutant strain BP108 was created by transduction of the $\operatorname{Tn} 917$ mutation of strain

Table 2. Kinetic parameters for betaine and proline transport by $S$. aureus

Initial rate determinations were performed as described in Methods. All determinations were completed at least twice and the data shown are the mean and standard deviation. HA, High affinity; LA, low affinity; ND, not detected.

\begin{tabular}{|c|c|c|c|c|c|c|c|c|}
\hline \multirow[t]{3}{*}{ Strain } & \multicolumn{4}{|c|}{ Betaine uptake system } & \multicolumn{4}{|c|}{ Proline uptake system } \\
\hline & \multicolumn{2}{|c|}{$\begin{array}{c}K_{\mathrm{m}} \\
(\boldsymbol{\mu} \mathbf{M})\end{array}$} & \multicolumn{2}{|c|}{$\begin{array}{c}V_{\max } \\
{[\mathrm{nmol}(\mathrm{mg} \text { total }} \\
\left.\text { protein })^{-1} \mathrm{~min}^{-1}\right]\end{array}$} & \multicolumn{2}{|c|}{$\begin{array}{c}K_{\mathrm{m}} \\
(\boldsymbol{\mu} \mathbf{M})\end{array}$} & \multicolumn{2}{|c|}{$\begin{array}{c}V_{\max } \\
{[\text { nmol }(\mathrm{mg} \text { total }} \\
\left.\text { protein })^{-1} \min ^{-1}\right]\end{array}$} \\
\hline & $\mathbf{H A}$ & LA & HA & LA & HA & LA & $\mathbf{H A}$ & LA \\
\hline RN4220 & $3 \cdot 0 \pm 0 \cdot 3$ & $133 \pm 14 \cdot 6$ & $26 \cdot 5 \pm 2 \cdot 9$ & $155 \pm 17 \cdot 1$ & $2 \cdot 4 \pm 0 \cdot 2$ & $1022 \pm 332$ & $2 \cdot 8 \pm 0 \cdot 8$ & $84 \cdot 0 \pm 4 \cdot 0$ \\
\hline BP101 & $4 \cdot 8 \pm 0 \cdot 4$ & $433 \pm 39 \cdot 0$ & $24 \cdot 5 \pm 2 \cdot 2$ & $62 \pm 8 \cdot 3$ & $2 \cdot 0 \pm 0 \cdot 4$ & $801 \pm 14$ & $2 \cdot 1 \pm 0 \cdot 1$ & $38 \cdot 3 \pm 4 \cdot 3$ \\
\hline BP106 & $5 \cdot 8 \pm 1 \cdot 2$ & ND & $27 \cdot 0 \pm 6 \cdot 3$ & ND & $18 \cdot 0$ & ND & $5 \cdot 5$ & ND \\
\hline BP108 & $10 \cdot 6 \pm 0 \cdot 1$ & ND & $29 \cdot 3 \pm 10 \cdot 8$ & ND & $8 \cdot 9$ & ND & $4 \cdot 1$ & ND \\
\hline
\end{tabular}


BP107 into the streptomycin-resistant strain BP100. The low affinity transport system was undetectable in this strain and in strain BP106 a spontaneous mutant isolated as resistant to $5 \mathrm{M} \mathrm{AC}$. In contrast, the high affinity transport system was fully active and comparable with that observed in strain RN4220 (Table 2). Thus, mutants that had acquired resistance to $\mathrm{AC}$ lost the low affinity glycine betaine transport system. Similarly, such mutants were found to have reduced activity of the low affinity proline transport system (Table 2). As was observed for glycine betaine transport, the low affinity proline transport system could not be detected in strain BP108, but the high affinity system was unaffected (Table 2). These data strongly support the hypothesis that the low affinity osmotically activated glycine betaine/proline transport systems are mediated by the same gene product.

\section{Regulation of accumulation of glycine betaine in $S$. aureus}

Glycine betaine accumulation is regulated by the osmotic pressure of the incubation medium, but it is not clear whether both systems contribute to the regulation of the pool of the compatible solute. We have previously shown that there are two glycine betaine transport systems in $S$. aureus that differ in their affinity for the substrate and in their activation by osmotic pressure (Pourkomailian \& Booth, 1992). The high affinity system is only slightly activated by osmotic pressure and this activity is expected to be dominant when the glycine betaine concentration is low $(1-20 \mu \mathrm{M}$, initial concentration). Under these conditions the glycine betaine accumulation was found to be relatively independent of the osmotic pressure and was predominantly determined by the amount of glycine betaine in the medium, since it can be calculated that the external glycine betaine concentration at the steady state is reduced to close to zero (Fig. 1a). In the mutant strain BP108 the glycine betaine pool was always lower than in the parent strain, suggesting that both transport systems contribute to accumulation even at very low glycine betaine concentrations. However, when the osmolarity was raised to 0.82 osm by the addition of $\mathrm{NaCl}$ the activity of the high affinity system was sufficient to accumulate virtually all of the glycine betaine present in the incubation mixture. This demonstrates the immense scavenging capacity of this transport system.

At higher concentrations of glycine betaine $(100-750 \mu \mathrm{M}$, initial concentration) the accumulation of the compatible solute was determined by the osmolarity of the growth medium (Fig. 1b). Under these conditions the steady stare concentration in the cells was independent of the external concentration and was dependent upon the osmolarity of the incubation medium. Although the external concentration of glycine betaine is reduced significantly below the initial concentration, the steady state external concentration is between $60 \%$ and $90 \%$ of the initial concentration (data calculated from Fig. 1b). Glycine betaine accumulation in strain BP108, which only possesses the high affinity transport system, was found to be substantially lower than that in strain RN4220 even at

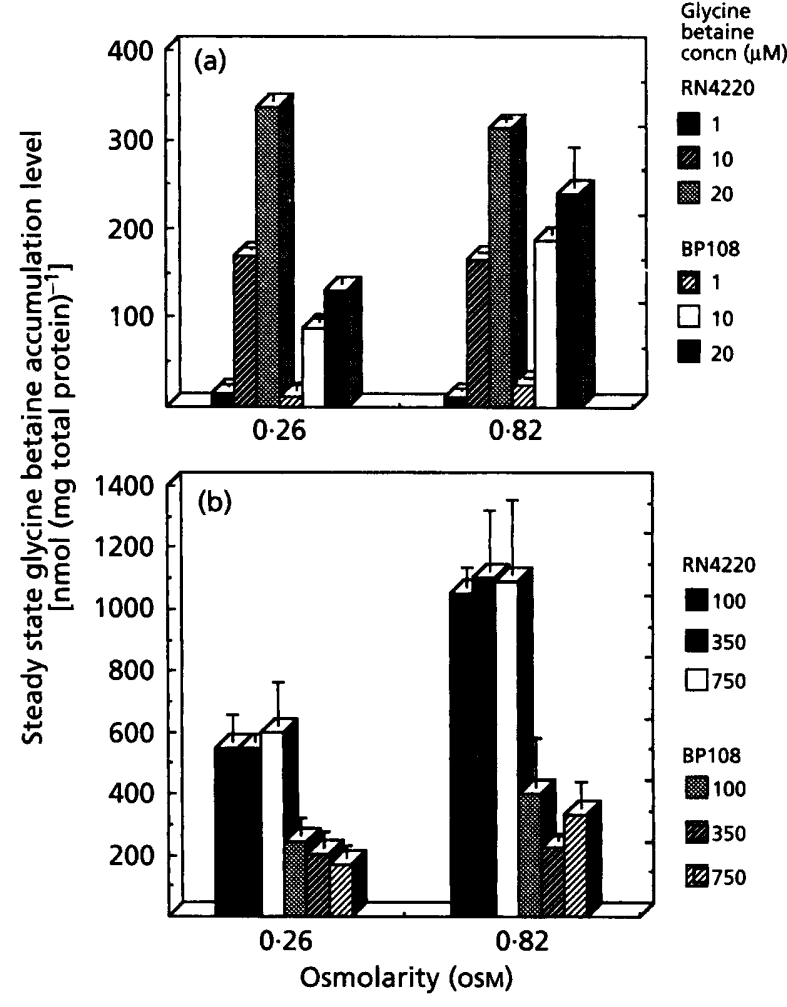

Fig. 1. Glycine betaine accumulation by osmotic pressure in strains RN4220 and BP108. Transport assays were conducted at $30^{\circ} \mathrm{C}$ in $45 \mathrm{mM}$ potassium phosphate buffer, $\mathrm{pH} 7$, containing $10 \mathrm{mM} \mathrm{NaCl}$ (approximately 0.12 osM). $\mathrm{NaCl}(0.5 \mathrm{M})$ was added to raise the osmolarity to $0.82 \mathrm{osM}$. Aliquots of cells $(2 \mathrm{ml})$ were incubated at approximately $60 \mu \mathrm{g}$ protein $\mathrm{ml}^{-1}\left(\mathrm{OD}_{600}=0.5\right)$ for $5 \mathrm{~min}$ prior to the addition of $\left[\mathrm{N}\right.$-methyl- $\left.{ }^{14} \mathrm{C}\right]$ glycine betaine, specific activity $0.4-55 \mu \mathrm{Ci} \mu \mathrm{mol}^{-1} \quad(1-750 \mu \mathrm{M})$, and the incubation continued until the steady state was reached (approximately $45 \mathrm{~min}$ ), at which time duplicate samples were taken and filtered and the radioactivity in the cells determined by scintillation counting as described in Methods. (a) Incubation with low glycine betaine concentrations $(1-20 \mu \mathrm{M})$. (b) Incubation with high glycine betaine concentrations $(100-750 \mu \mathrm{M})$.

high osmolarity (Fig. 1). All of the spontaneous mutants were also found to exhibit reduced rates of glycine betaine transport and failed to accumulate high levels of this compatible solute when incubated at high osmolarity (data not shown). Thus, osmotically regulated glycine betaine accumulation is primarily due to the activity of the osmotically activated low affinity system.

\section{Regulation of transport activity}

The regulation of the glycine betaine pool by osmotic pressure suggested that the transport systems might be subject to control mechanisms in addition to activation of the low affinity system by osmotic pressure, as demonstrated previously (Pourkomailian \& Booth, 1992). To investigate this possibility, the initial rate and the exchange rate at the steady state were investigated. Cell 


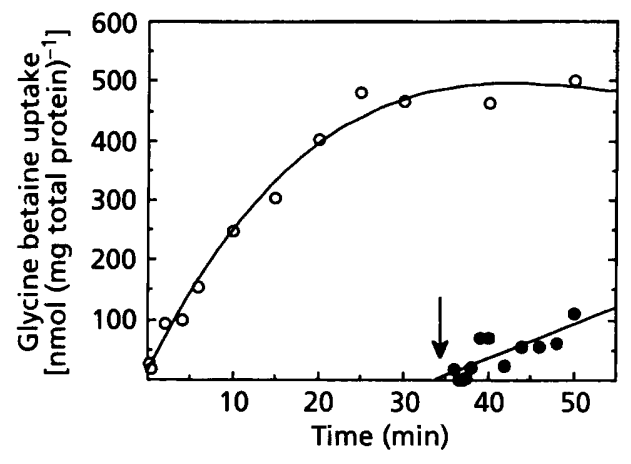

Fig. 2. Comparison of steady state exchange rate and the initial rate of glycine betaine transport. Cell suspensions were treated as described in Fig. 1 at a final osmolarity of 0.26 osM. The initial glycine betaine concentration was $500 \mu \mathrm{M}$ (specific activity $2 \mu\left(\mathrm{Cimol}^{-1}\right)$. For initial rate determinations (O) radiolabelled glycine betaine was added at zero time and the rate of transport determined in the normal manner. To determine the steady state rate of uptake (O) cells were incubated with unlabelled glycine betaine and $200 \mathrm{nCi}$ radiolabelled glycine betaine $\left(55 \mu \mathrm{Ci} \mu \mathrm{mol}^{-1}\right.$ stock) added at the steady state (arrow). The final specific activity was calculated from the known addition of radioactivity and the estimated steady state external glycine betaine concentration calculated from the observed accumulation (O). Uptake of the radiolabelled material was assayed as described in Methods.

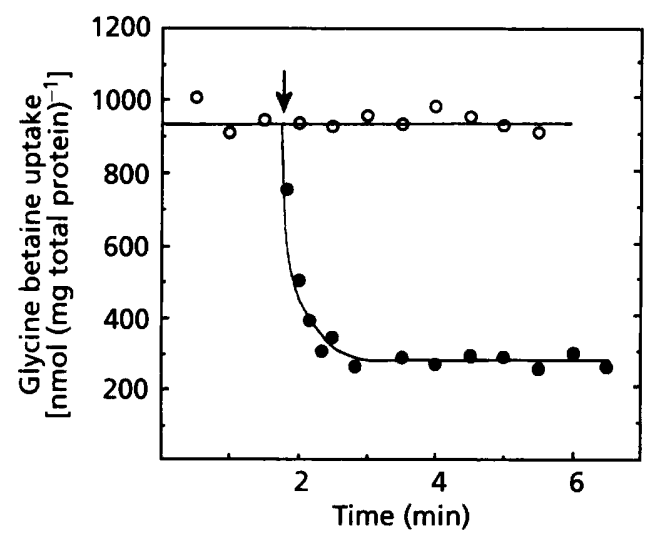

Fig. 3. Glycine betaine retention. Cells were loaded with $500 \mu \mathrm{M}$ glycine betaine as described in Fig. 2; the suspension was harvested by filtration, washed and re-suspended in isoosmotic medium lacking glycine betaine. Samples were taken as described in Methods and the retained glycine betaine pool determined by scintillation counting. $O$. No additions; $25 \mu \mathrm{M}$ CCCP added at arrow.

suspensions were incubated with $500 \mu \mathrm{M}$ glycine betaine, such that the pool achieved the maximum level attainable (Fig. 1b), and the exchange rate determined by addition of a trace amount of radiolabelled glycine betaine (Fig. 2). The rate of glycine betaine exchange was reduced to approximately $20 \%$ of the initial rate of transport observed in a parallel incubation (Fig. 2). Thus, when
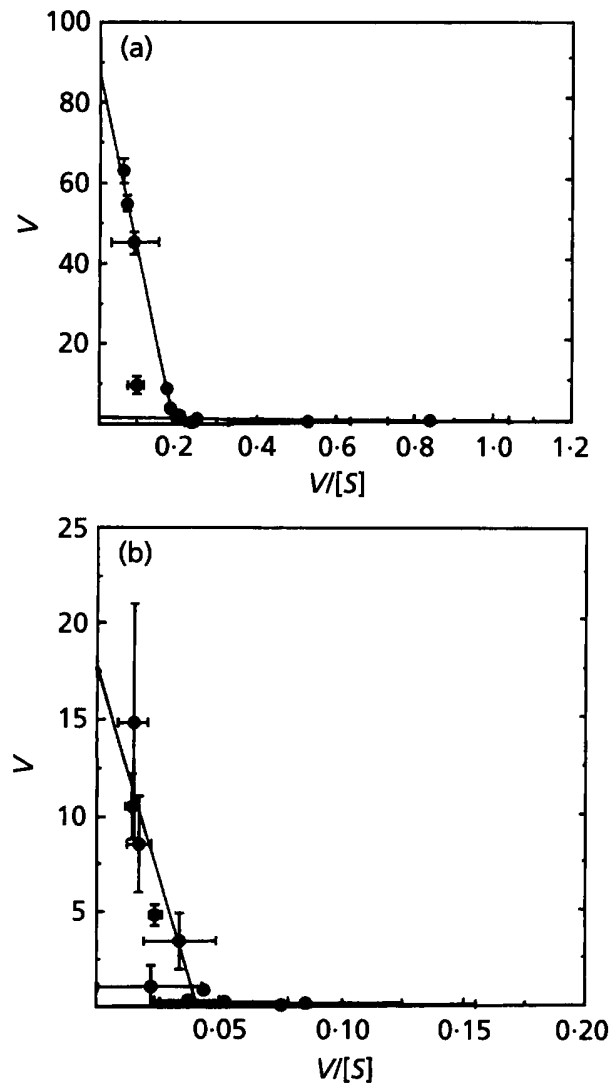

Fig. 4. Eadie-Hofstee plots of glycine betaine accumulation by S. aureus RN4220. Cells were pre-loaded with unlabelled glycine betaine as described in Fig. 2 and the cells incubated with radiolabelled glycine betaine $(0.5-2000 \mu \mathrm{M}$, specific activity $\left.0.4-20 \mu \mathrm{Ci} \mathrm{mol}^{-1}\right)$ and the initial rate of transport determined over $2 \mathrm{~min}$. The final osmolarity of the incubation was 0.26 osM. (a) Cells pre-loaded with $500 \mu \mathrm{M}$ glycine betaine. (b) Cells preloaded with $20 \mu \mathrm{M}$ glycine betaine.

cells have achieved a satisfactory glycine betaine pool, one or more of the transport systems is inhibited.

Since either transport system could be subject to inhibition, the kinetic parameters of the two transport systems were investigated in cells that had been preloaded with glycine betaine. Cells were pre-incubated with $500 \mu \mathrm{M}$ unlabelled glycine betaine for $30-40 \mathrm{~min}$, collected by filtration, washed and resuspended with isotonic buffer, and the $K_{\mathrm{m}}$ and $V_{\max }$ of the two transport systems were determined. Since the cells contained high levels of glycine betaine a control experiment was conducted to ensure that leakage of unlabelled glycine betaine from the cells did not interfere with the assay of the influx rate. Thus, cells incubated with radiolabelled glycine betaine and harvested by filtration were incubated in medium free of glycine betaine (Fig. 3). Glycine betaine did not exit from the cells over the $6 \mathrm{~min}$ period equivalent to that used for assay of the uptake rate in $K_{\mathrm{m}}$ and $V_{\max }$ determinations. Retention was energy-dependent since addition of CCCP elicited rapid glycine betaine efflux (Fig. 
3). Similarly, addition of an excess of unlabelled glycine betaine elicited rapid exchange of the accumulated material (data not shown).

Kinetic plots of glycine betaine transport into cells that had been pre-incubated with glycine betaine showed greater experimental error than studies with cells not preloaded, but the data revealed only a single transport system, with $K_{\mathrm{m}} 450-525 \mu \mathrm{M}$ and a $V_{\max }$ of 18-21 nmol $\mathrm{min}^{-1}$ (mg protein) ${ }^{-1}$ (Fig. 4a). This represents a threefold reduction of the affinity for glycine betaine and a fivefold reduction in the $V_{\max }$. The high affinity transport system was not detected in cells pre-treated with $500 \mu \mathrm{M}$ glycine betaine (Fig. 4a). These data are consistent with the reduced exchange rate seen at the steady state in cells incubated with $500 \mu \mathrm{M}$ glycine betaine (Fig. 2b). When cells were pre-loaded with an intermediate glycine betaine concentration $(20 \mu \mathrm{M})$ both transport systems were still active, but the high affinity system had a reduced $V_{\max }$ of $2 \cdot 6$, compared with $26 \mathrm{nmol} \mathrm{m^{-1 }}$ (mg protein $)^{-1}$ in cells not pre-incubated with glycine betaine. The $V_{\max }$ of the low affinity transport system was reduced slightly to 88 , compared with $150 \mathrm{nmol} \mathrm{min}{ }^{-1}$ (mg protein) $)^{-1}$ in cells not pre-incubated with glycine betaine (Fig. $4 \mathrm{~b}$ ). These data are consistent with both the high affinity and the low affinity transport systems being subject to feedback inhibition by the pre-accumulated glycine betaine pool.

\section{DISCUSSION}

The data presented in this paper confirm the existence of two separate glycine betaine transport systems in $S$. aureus. Mutants isolated for their resistance to the toxic analogue AC were impaired in the low affinity transport system, but the high affinity system was unaffected. The analysis of these mutants also provides further support for our previous assertion that a single system is responsible for the low affinity, osmotically regulated transport activity for proline and glycine betaine (Pourkomailian \& Booth, 1992), since both activities were lost in the mutants. Data obtained with point mutations can often be misleading, but the isolation of single transposon insertions that eliminate both the osmotically activated glycine betaine and proline transport systems is most simply explained by their being conducted by the same protein. It is possible that the transposon inactivates a regulatory gene that controls the expression of separate proline and glycine betaine transport systems. However, while we cannot definitively eliminate this possibility, both systems are expressed constitutively by cells and there are no data to suggest regulation of their expression that would necessitate this more complex model. Further, the transposon data are consistent with the previous demonstration that glycine betaine uptake via the low affinity system is inhibited by proline and vice versa (Pourkomailian \& Booth, 1992).

We have established that both of the glycine betaine transport systems are subject to feedback inhibition by pre-accumulated solute. This represents a novel mechanism of regulation of compatible solute accumulation.
The high affinity system is more seriously affected by the regulatory mechanism and is almost undetectable in cells pre-incubated with $500 \mu \mathrm{M}$ glycine betaine. However, the low affinity system is also subject to regulation since the $V_{\max }$ of this system is significantly reduced in cells preloaded with glycine betaine. These data may also explain why other groups had suggested a single glycine betaine transport system. Their studies were conducted primarily with cells grown in broth, which contains glycine betaine and proline. Accumulation of these compatible solutes by cells would cause the inactivation of the high affinity glycine betaine transport system. In our experiments we found that kinetic plots obtained with pre-loaded cells showed much greater experimental variability than similar data obtained with cells that had not been pre-incubated with glycine betaine. This observation has also been made with assays conducted on cells grown in broth (Stimeling et al., 1994). Recent studies comparing the transport kinetics of cells grown in different media have concluded that cells grown in broth show a single glycine betaine transport system, whereas two systems were found in cells grown in defined medium (Stimeling et al., 1994). Further, those studies revealed that cells grown in defined medium and pre-incubated with glycine betaine exhibited similar kinetics to those grown in broth and confirm our observation of feedback regulation of glycine betaine transport activity (Stimeling et al., 1994).

Incubation of the cells with glycine betaine resulted in the inactivation of the high affinity system and reduced activity of the low affinity system. Previous work has shown that the two transport systems are essentially constitutive, since they are present in cells grown under conditions of low osmolarity. Our data suggest that the transport systems are inactivated rather than repressed, since the studies were conducted with non-growing cells that had been incubated for only a short time with the unlabelled glycine betaine prior to the kinetic analysis. This system of regulation is unique in so far as no evidence for feedback regulation of the activity of the compatible solute transport systems has been seen in this or other organisms (Booth et al., 1988; Csonka, 1989). The model, based primarily on our data, is that the high affinity transport system exists to scavenge for glycine betaine and its efficiency is indicated by the ability of cell suspensions to reduce the external glycine betaine concentration from $20 \mu \mathrm{M}$ to close to zero, particularly when the cells are incubated at high osmolarity $(0.82$ osm; Fig. 1b). This ability might constitute a hazard to normal osmoregulation when cells are in environments with significant glycine betaine or proline pools. Consequently, once sufficient glycine betaine has been accumulated this system is closed down. If the organism is subjected to osmotic stress the low affinity system is activated and if sufficient glycine betaine is available a large pool is established in the cytoplasm. The magnitude of the pool is determined primarily by the degree of osmotic stress (Fig. $1 b)$. When sufficient glycine betaine has been accumulated the activity of the uptake system is reduced. Thus, the low affinity system must be capable of sensing both the internal glycine betaine pool (either directly or indirectly) 
and the external osmolarity. In contrast, the high affinity system is not activated by osmotic stress (Pourkomailian \& Booth, 1992) but is inhibited by the accumulation of glycine betaine by osmotically stressed cells. In many ways this pattern of regulation compares with that for potassium transport in enteric bacteria. The constitutive Trk systems have been shown to be activated by osmotic stress and there are suggestions that they are also subject to feedback inhibition (Rhoads \& Epstein, 1978; Meury $e t$ al., 1985; Epstein, 1986; Booth et al., 1988). In this instance the regulation is via changes in the turgor pressure. In $S$. aureus there is no clear involvement of potassium transport in turgor regulation and it may be that it is the flux of glycine betaine that restores turgor. Control of the low affinity system would be exerted through activation by low turgor followed by inactivation after accumulation of sufficient glycine betaine to restore turgor. The intermediate transport kinetics seen in cells loaded with $20 \mu \mathrm{M}$ glycine betaine, which is insufficient to fulfil the osmotic requirements of the cell (Fig. 1a, b), would be consistent with this model.

We have previously shown that the Escherichia coli glycine betaine transport system ProP, which is the nearest equivalent of the low affinity system in $S$. aureus, is not subject to feedback inhibition and that it is inhibited, rather than activated, by low turgor (Koo et al., 1991). S. aureus and E. coli belong to different subdivisions of the bacterial kingdom and this is in part reflected by their respective turgor pressures, which have been estimated to lie in the 20 and 3-4 atmosphere ranges, respectively (Mitchell \& Moyle, 1956). One consequence of these different turgor pressures may be that these two organisms have adopted very different initial responses to osmotic stress. The enteric bacteria are able to take advantage of the ubiquitous potassium ion for their turgor restoration without initially impairing cell function. In contrast, the high turgor of $S$. aureus, which derives from high solute pools in the cytoplasm, may have precluded the evolution of potassium transport mechanisms to regulate cell turgor and have led to the dependence upon glycine betaine (or compounds that can be converted to this osmolyte). If turgor is the main regulator of the low affinity glycine betaine/proline transport system then this would represent a major evolutionary adaptation to the possession of high turgor.

\section{NOTE ADDED IN REVISION}

This analysis was extended to proline transport, which is dependent upon two transport systems, a proline-specific high affinity system and the osmotically activated, low affinity, proline/betaine system (Bae \& Miller, 1992; Pourkomailian \& Booth, 1992). The kinetics of proline transport were analysed in cells of strain RN4220 that had been pre-loaded by incubation with $500 \mu \mathrm{M}$ glycine betaine as described above (see legend to Fig. 4). In cells that had been pre-loaded with glycine betaine the high affinity proline transport system was undetectable and the $V_{\max }$ of the low affinity system was reduced almost 30 -

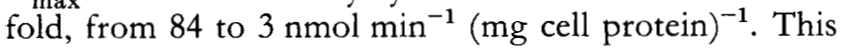

suggests that the high affinity proline and betaine transport systems, though separate proteins, are regulated in the same manner by compatible solute accumulation.

\section{ACKNOWLEDGEMENTS}

The authors wish to thank the AFRC and Unilever Plc for a research studentship to B.P. They would also like to thank $\mathrm{Dr}$ G. S. A. B. Stewart for supplying bacterial strains; Professor T. J. Foster for the provision of plasmid pTV1ts and bacteriophage $\phi 85$ and for much helpful advice on mutant generation and analysis in S. aureus; Brian Wilkinson and Karen Miller for pre-publication information and for helpful discussions; and Dr D. McLaggan for her helpful comments.

\section{REFERENCES}

Anderson, C. B. \& Witter, L. D. (1982). Glutamine and proline accumulation by Staphylococcus aureus with reduction in water activity. Appl Environ Microbiol 43, 1501-1503.

Bae, J.-H. \& Miller, K. J. (1992). Identification of two proline transport systems in Stapbylococcus aureus and their possible role in osmoregulation. Appl Environ Microbiol 58, 471-475.

Bae, J.-H., Anderson, S. H. \& Miller, K. J. (1993). Identification of a high affinity glycine betaine transport in Staphylococcus aureus. Appl Environ Microbiol 59, 2734-2736.

Booth, I. R., Cairney, J., Sutherland, L. \& Higgins, C. F. (1988). Enteric bacteria and osmotic stress: an integrated homeostatic system. J Appl Bacteriol Symp Suppl 35S-49S.

Csonka, L. N. (1989). Physiological and genetic responses of bacteria to osmotic stress. Microbiol Rev 53, 121-147.

Epstein, W. (1986). Osmoregulation of potassium transport in Escherichia coli. FEMS Microbiol Rev 39, 73-78.

Graham, J. E. \& Wilkinson, B. J. (1992). Staphylococcus aureus osmoregulation: roles for choline, glycine betaine, proline and taurine. J Bacteriol 174, 2711-2716.

Kaenjak, A., Graham, J. E. \& Wilkinson, B. J. (1993). Choline transport activity in Staphylococcus aureus induced by osmotic stress and low phosphate concentrations. J Bacteriol 175, 2400-2406.

Koo, S.P., Higgins, C. F. \& Booth, I. R. (1991). Regulation of compatible solute accumulation in Salmonella typhimurium: evidence for a glycine betaine efflux system. J Gen Microbiol 137, 2617-2625.

Koujima, I., Hayashi, H., Tomochika, A., Okaba, A. \& Kanemasa, Y. (1978). Adaptational change in proline and water content after alteration of environmental salt concentration. Appl Environ Microbiol 35, 467-470.

Meury, J., Robin, A. \& Monier-Champeix, P. (1985). Turgorcontrolled $\mathrm{K}^{+}$fluxes and their pathways in Escherichia coli. Eur $J$ Biocbem 151, 613-619.

Miller, K. J., Zelt, S. C. \& Bae, J.-H. (1991). Glycine betaine and proline are the principal compatible solutes of Stapbylococcus aureus. Curr Microbiol 23, 131-137.

Mitchell, P. \& Moyle, J. (1956). Osmotic function and structure in bacteria. Symp Soc Gen Microbiol 6, 150-180.

Pattee, P. A. \& Neveln, D. S. (1975). Transformation analysis of three linkage groups in Staphylococcus aureus. J Bacteriol 124, 201-211.

Pourkomailian, B. \& Booth, I. R. (1992). Glycine betaine transport by Staphylococcus aureus: evidence for two transport systems and for their possible roles in osmoregulation. J Gen Microbiol 138, 2515-2518.

Rhoads, D. E. \& Epstein, W. (1978). Cation transport in Eschericbia 
coli IX. Regulation of potassium transport. J Gen Physiol 72, 283-295.

Rowland, G. C., Giffard, P. M. \& Booth, I. R. (1984). Genetic studies of the phs locus of Escherichia coli, a mutation causing pleiotropic lesions in metabolism and $\mathrm{pH}$ homeostasis. FEBS Lett 173, 295-300.

Stimeling, K. W., Graham, J. E., Kaenjak, A. \& Wilkinson, B. J. (1994). Evidence for feedback (trans) regulation of, and two systems for, glycine betaine transport in Stapbylococcus aureus. Microbiology 140, 3139-3144.

Townsend, D. E. \& Wilkinson, B. J. (1992). Proline transport in Staphylococcus aureus: a high affinity system and a low affinity system involved in osmoregulation. J Bacteriol 174, 2702-2710.

Received 15 March 1994; revised 23 June 1994; accepted 4 August 1994. 